\title{
ENERGY AND EXERGY ANALYSIS OF A 3×500 MW COAL FIRED THERMAL POWER PLANT USING CYCLE-TEMPO
}

\author{
VISHNU RAJEEV, M. SREEKANTH, M. FEROSKHAN \& JOSEPH DANIEL
}

School of Mechanical Engineering, Vellore Institute of Technology Chennai

\begin{abstract}
This study deals with an energy and exergy analysis of a coal fired $3 \times 500 \mathrm{MW}$ thermal power plant located in South India. The platform used for simulation and analysis is Cycle-Tempo. In this article, the parameters of mass flow rate and temperatures at different state points of the thermal power plant were validated using the simulations carried out in CycleTempo. It was found from the analysis the operating parameters like temperatures, flow rates etc. Obtained using CycleTempo fall within an acceptable range of error. Maximum exergy loss was found to occur in the combustor (36.5\%), and the least exergy loss occurred in the de-aerator (0.13\%). Optimization of the power plant was carried out, and the energy and exergy efficiency values obtained for the power plant were $34.35 \%$ and $33.64 \%$.

KEYWORDS: Coal, Thermal Power Plant, Energy Analysis, Exergy Analysis, Cycle-Tempo
\end{abstract}

Received: May 12, 2020; Accepted: Jun 02, 2020; Published: Jul 17, 2020; Paper Id.: IJMPERDJUN2020368

\section{INTRODUCTION}

A huge portion of the energy requirements of the world is met by thermal power plants. Steam turbine power plants are capable of delivering power outputs up to $2000 \mathrm{MW}$. Since the performance of steam turbine power plants are limited by the laws of thermodynamics, the maximum thermal efficiency they can deliver is around 60\% [1]. A basic steam turbine power plant consists of a boiler, turbine, condenser and a pump. Additional components like re heaters and feed water heaters increase the thermal efficiency of the plant. Siva Reddy et. al. [2] observed that there has been an increase in energy generated from coal by $2.3 \%$ every year from 2007 , and this is expected to continue till 2035. They have predicted a production of 15 trillion $\mathrm{kWh}$ energy from coal alone. Such a situation demands the need to increase the efficiency of existing power plants. Exergy analysis is what determines the usefulness of the available energy. Any modification in the operating parameters of the power plants, retro-fitting of new components etc. must be based on the exergy analysis rather than the energy analysis. This is because exergy pin points to the location where useful energy is destroyed. The exergy efficiency is also known as the second law efficiency.

In a study conducted by Regulagadda et. al. [3] and Ravinder Kumar [4], it was observed that maximum exergy destruction takes place in the boiler. They also concluded that the efficiency increases with an increase in temperature and steam pressure, whereas the efficiency decreases with an increase in condenser pressure. $\mathrm{Li}$ and Liu [5] also concluded that the boiler is the source of the largest exergy destruction in their exergy analysis of a 300 MW coal fired thermal power plant. According to a study conducted by Mohamed Elhelw et. al. [6], after the boiler, the turbines is where the highest exergy loss takes place. Exergy analysis can help in identifying the magnitude and the sources of such thermodynamic inefficiencies [7]. Wenjun Li et. al. [8] found that temperature-based exergy accounts for a large fraction of the total exergy losses. In an attempt to increase the thermal efficiency, Hasan Huseyin Erdema et. al. [9] found that increasing the boiler output pressure lead to the required result. In their 
article, Aleksandr M. Kler et. al. [10] stated that 'Reducing the waste gas temperature can lead to a reduction in temperature difference in convective heat exchangers and an increase in the area of heating surfaces'. Even when the temperature difference is very small at one end of the heat exchanger, there will still be appreciable irreversibility rate due to heat transfer over a finite temperature difference at other points in the heat exchanger [11]. By varying the steam generator pressure, exergy destruction can be reduced. This mode of operation is also known as Sliding Pressure Operation [12]. The net generated power and overall exergy efficiency of the power plant can be increased by the addition of a heat and water recovery system [13]. Shivendra Singh Chauhan and Shabina Khanam [14], in their article, stated that combustion process leads to the most exergy destruction. M.K. Gupta and S.C. Kaushik [15], in their studies, were able to conclude that condensers are the source of least exergy losses, whereas maximum energy loss takes place in the condenser. Okoand Njoku [16] found out that the exergy efficiency and power output dropped with rising ambient temperature. The decrease in isentropic efficiency of a component leads to an increase in exergy destruction [17]. Periodic cleaning of the condenser pipes can help in increasing the efficiency of both the condenser, as well as the plant [18].By using a counter flow schematic in the boiler, not only does the boiler efficiency increase, but the amount of pollutants produced decreases [19].

The coal fired thermal power plant studied in this article consists of three turbines, a steam generator apparatus, five feed water heaters, a de-aerator and a condenser. The exergy analysis gives detailed insights on the amount of exergy lost in each apparatus. The inlet pressure values of the feed water heaters and the de-aerator were optimized in order to increase the overall efficiency of the plant.

\section{METHODOLOGY}

All calculations related to exergy and energy is based on the standard concepts of exergy balance and energy conservation.

The following notations and equations have been adopted from Cengel and Boles [20]

\section{Energy Balance in a Steady Flow System}

$$
\Sigma_{\text {in }} E=\Sigma_{\text {out }} E
$$

For Multiple Streams,

$$
Q-W=\Sigma_{\text {out }} \dot{m}\left(h+\frac{W^{2}}{2}+g z\right)-\Sigma_{\text {in }} \dot{m}\left(h+\frac{W^{2}}{2}+g z\right)
$$

For a Single Stream,

$$
Q-W=\dot{m}\left[h_{2}-h_{1}+\frac{w_{2}^{2}-W_{1}^{2}}{2}+g\left(z_{2}-z_{1}\right)\right]
$$

Exergy Balance in a Steady Flow System

$$
\begin{aligned}
& \ddot{X}_{\text {in }}-\ddot{X}_{\text {out }}-\ddot{X}_{\text {destroyed }}=0 \\
& \dot{X}_{\text {heat }}=\left(1-\frac{T_{0}}{T}\right) \dot{Q} \\
& \tilde{X}_{\text {work }}=W_{\text {usef } \mathrm{ul}}
\end{aligned}
$$




$$
\begin{aligned}
& \dot{X}_{\text {mass }}=\dot{m} \psi \\
& \psi=\left(h-h_{0}\right)-T_{0}\left(s-s_{0}\right)+\frac{v^{2}}{2}+g z \\
& \dot{X}_{\text {destroyed }}=T_{0} S_{\text {gen }}
\end{aligned}
$$

Reversible work or the maximum possible work, in a combustion process that does not involve any work, is equal to the exergy destroyed, and can be calculated as follows:

$$
\begin{aligned}
& W_{\text {rev }}=\dot{X}_{\text {destroyed }}=\sum N_{r}\left(\bar{h}_{f}^{0}+\bar{h}-\bar{h}^{0}+T_{0} \bar{s}\right)_{r}-\sum N_{p}\left(\bar{h}_{f}^{0}+\bar{h}-\bar{h}^{0}+T_{0} \bar{s}\right)_{p} \\
& \eta_{L}=\frac{W_{\text {usaful }}}{Q_{\text {input }}} \\
& \eta_{I I}=\frac{W_{\text {useful }}}{W_{\text {reversible }}}=\frac{\eta_{I}}{\eta_{\text {reversible }}}=\frac{x_{\text {recovered }}}{X_{\text {supplied }}}
\end{aligned}
$$

\section{RESULTS}

Modelling of the $500 \mathrm{MW}$ power plant was carried out in Cycle-Tempo. The fuel used was coal from East Bokaro coal mine, situated in Jharkhand, India. Standard air was used as the source of air. The composition of fuel and air are mentioned in the Tables 1 and 2 given below. A pressure of 1 atm and a temperature of $30^{\circ} \mathrm{C}$ was defined as the environment conditions, which are required for carrying out the exergy analysis. The inlet pressure values of all the lowpressure feed water heaters and the de-aerator were optimized, to maximize the efficiency.

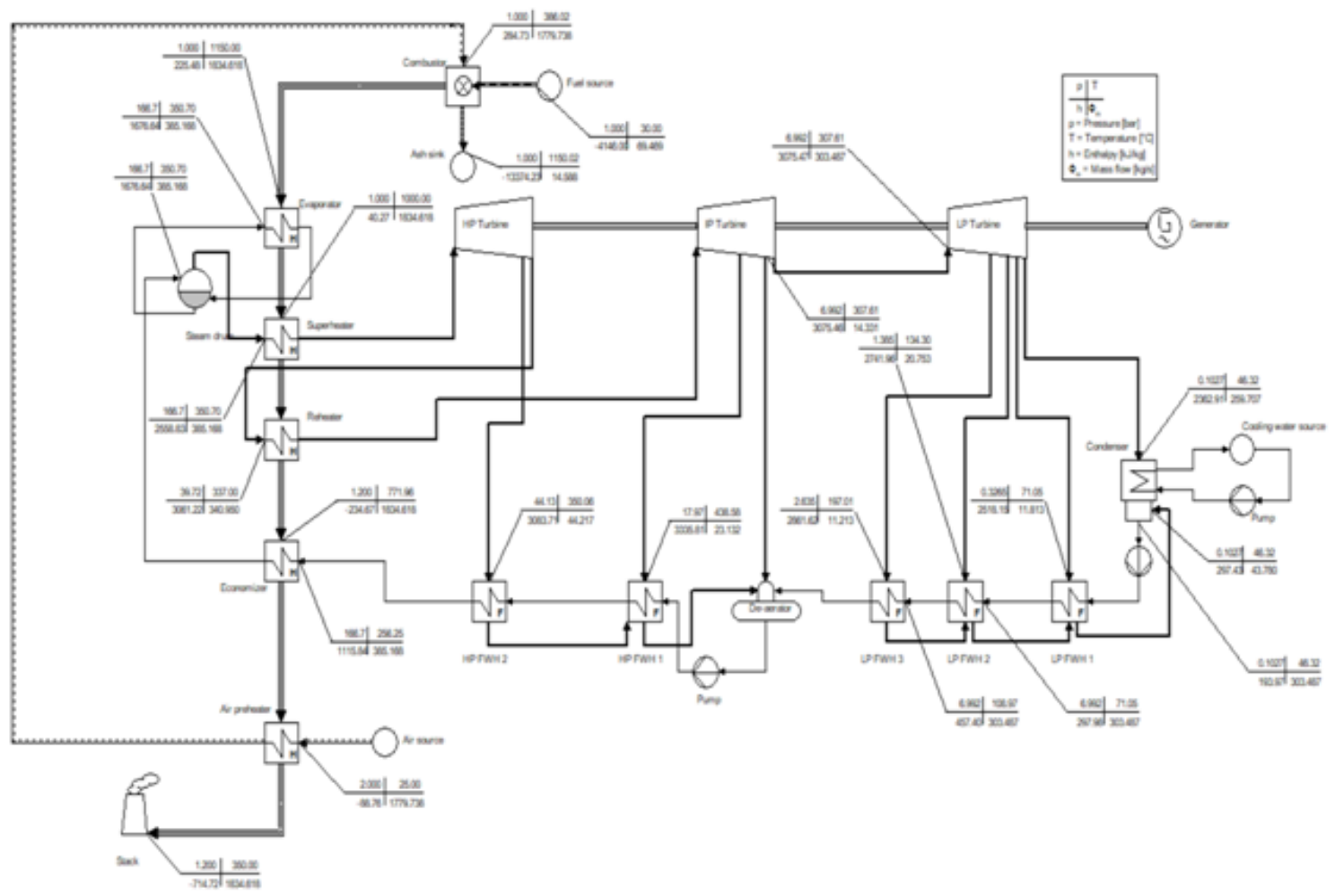

Figure 1: Model of the Power Plant Created using Cycle-Tempo. 
Table 1: Composition of the Coal Used

\begin{tabular}{|c|c|}
\hline Component & Mass \% \\
\hline $\mathrm{C}$ & 61.0 \\
\hline $\mathrm{H}_{2}$ & 4.1 \\
\hline $\mathrm{H}_{2} \mathrm{O}$ & 4.68 \\
\hline $\mathrm{N}_{2}$ & 1.53 \\
\hline $\mathrm{O}_{2}$ & 7.2 \\
\hline $\mathrm{S}(\mathrm{s})$ & 0.49 \\
\hline $\mathrm{SiO}_{2}$ & 21.0 \\
\hline Total & $\mathbf{1 0 0 . 0}$ \\
\hline
\end{tabular}

Table 2: Composition of Air Used

\begin{tabular}{|c|c|}
\hline Component & Mole \% \\
\hline $\mathrm{Ar}$ & 0.92 \\
\hline $\mathrm{CO}_{2}$ & 0.3 \\
\hline $\mathrm{H}_{2} \mathrm{O}$ & 1.01 \\
\hline $\mathrm{N}_{2}$ & 77.29 \\
\hline $\mathrm{O}_{2}$ & 20.75 \\
\hline Total & $\mathbf{1 0 0 . 0}$ \\
\hline
\end{tabular}

Table 3: Variation in Temperatures and Mass Flow Rates

\begin{tabular}{|c|l|c|c|c|c|c|c|}
\hline \multirow{2}{*}{ SI No. } & \multirow{2}{*}{ State Point } & \multicolumn{2}{|c|}{ Mass Flow Rate, m $(\mathbf{k g} / \mathbf{s})$} & \multicolumn{2}{|c|}{ Temperature, T $\left({ }^{\circ} \mathbf{C}\right)$} & \multicolumn{2}{c|}{ Error \% } \\
\cline { 3 - 8 } & Actual & Cycle Tempo & Actual & Cycle Tempo & Mass Flow Rate & Temperature \\
\hline 1 & Boiler outlet & 404.72 & 385.16 & 537 & 537 & 4.83 & 0 \\
\hline 2 & Reheater inlet & 361.45 & 340.95 & 337 & 337 & 5.67 & 0 \\
\hline 3 & LP turbine inlet & 296.32 & 303.48 & 309.9 & 307.61 & 2.41 & 0.73 \\
\hline 4 & Condenser inlet & 259.68 & 259.70 & 46.6 & 46.32 & 0.009 & 0.6 \\
\hline 5 & Condenser outlet & 320.27 & 303.48 & 46.4 & 46.32 & 5.24 & 0.17 \\
\hline 6 & LP Heater 1 inlet & 11.01 & 11.81 & 72.4 & 71.05 & 7.23 & 1.86 \\
\hline 7 & LP Heater 2 inlet & 19.98 & 20.75 & 147.7 & 134.3 & 3.82 & 9.07 \\
\hline 8 & LP Heater 3 inlet & 11.31 & 11.21 & 208.4 & 197.01 & 0.86 & 5.46 \\
\hline 9 & HP Heater 1 inlet & 24.28 & 23.13 & 444.5 & 438.58 & 4.73 & 1.33 \\
\hline 10 & HP Heater 2 inlet & 41.56 & 44.21 & 334.8 & 350.06 & 6.37 & 4.55 \\
\hline
\end{tabular}

\section{Validation}

In the comparative study that was carried out, the temperature and mass flow rates at 10 different points were compared and tabulated below, as follows. The power output was fixed at $500 \mathrm{MW}$.

Further, various parameters like inlet air temperature, condenser pressure, etc. were varied to monitor how these changes affected the energy and exergy efficiency. The results have been displayed in the form of graphs below. 


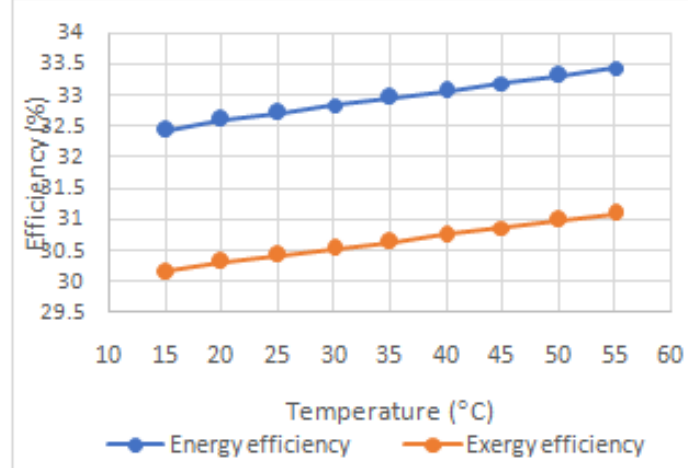

Figure 2: Variation of Efficiency with Inlet Air Temperature.

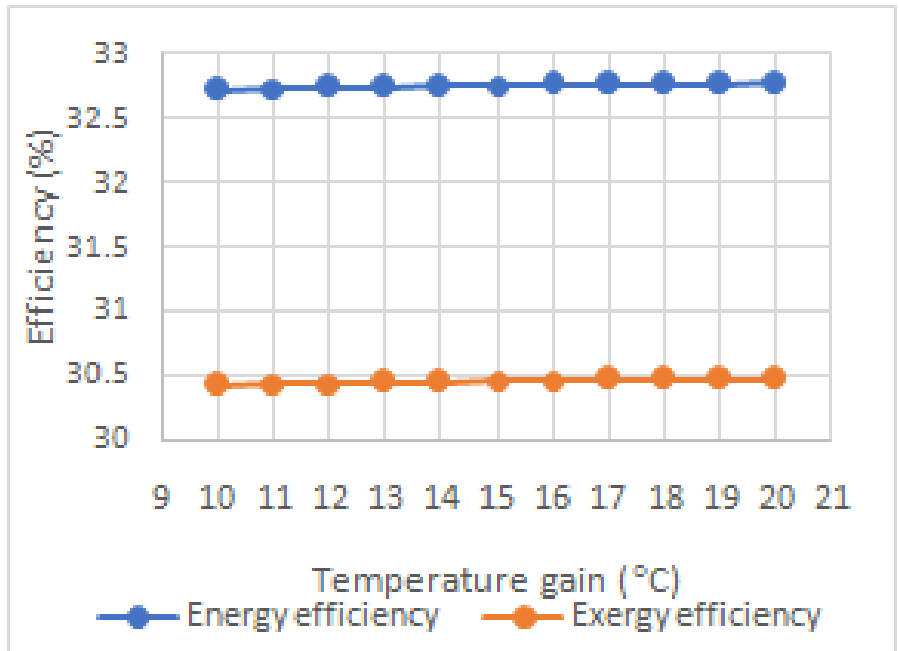

Figure 3: Variation of Efficiency with Gain in Cooling Water Temperature.

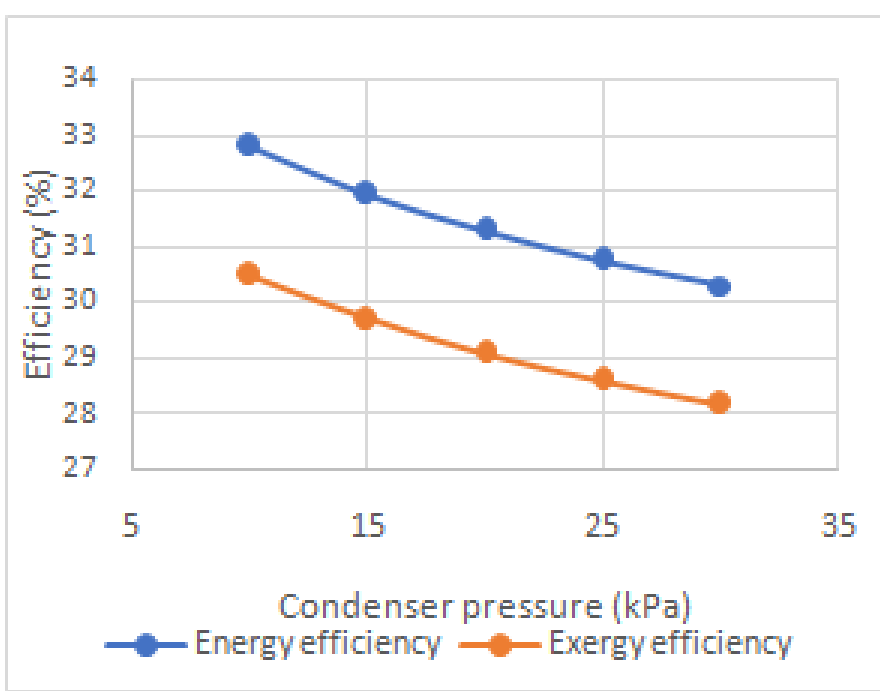

Figure 4: Variation of Efficiency with Condenser Pressure. 


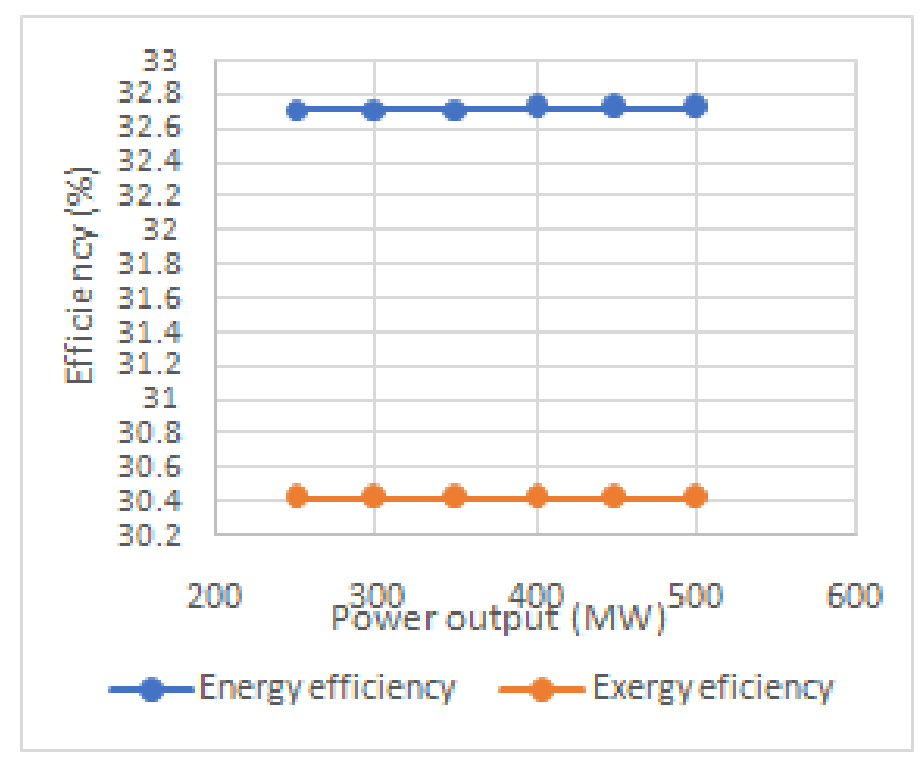

Figure 5: Variation of Efficiency with Power Output.

It was observed that efficiency of the power plant increased when the temperature of the inlet air to the combustor was increased (figure 2). Efficiency increased slightly with increase in the gain in temperature of cooling water, as well as with power output (figures 3 and 5). On the other hand, efficiency was found to decrease with increase in condenser pressure (figure 4).

\section{EXERGY ANALYSIS}

The exergy analysis was carried out in Cycle-Tempo using a user defined environment. A pressure of 1 atm and a temperature of $30^{\circ} \mathrm{C}$ were used as the environment condition for the exergy analysis. An Exergy loss at each component of the power plant was determined through this exergy analysis. The resultshave been tabulated and visualized in the Sankey diagram in Fig 6.

Table 4: Exergy Loss at each Component

\begin{tabular}{|c|l|c|}
\hline SI No. & \multicolumn{1}{|c|}{ Apparatus } & Exergy Loss (\%) \\
\hline 1 & Turbines & 2.06 \\
\hline 2 & Condenser & 2.83 \\
\hline 3 & Stack & 6.58 \\
\hline 4 & Combustor & 36.5 \\
\hline 5 & $\begin{array}{l}\text { Steam Generator } \\
\text { (excluding combustor) }\end{array}$ & 15.61 \\
\hline 6 & Feed water heaters & 0.7 \\
\hline 7 & De-Aerator & 0.13 \\
\hline 8 & Pumps and Pipes & 1.95 \\
\hline Total & \multicolumn{2}{|c|}{$\mathbf{6 6 . 3 6}$} \\
\hline
\end{tabular}




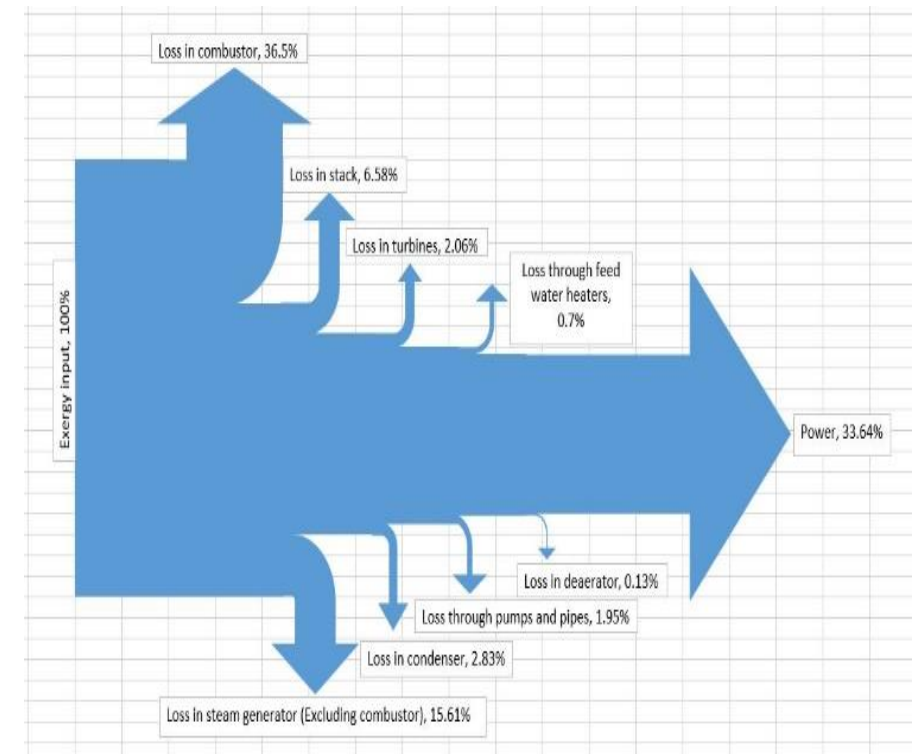

Figure 6: Sankey Diagram Representing Exergy Losses.

The combustor was found to be the biggest source of exergy destruction, in which $36.5 \%$ of the total available exergy was lost. The steam generating apparatus including the combustor accounts for $52.11 \%$ of the total exergy loss. The least exergy loss took place in the de-aerator. The total exergy lost was found to be $66.36 \%$. The remaining fraction of exergy is the second law efficiency or the exergy efficiency of the plant, which is $33.64 \%$.

\section{CONCLUSIONS}

A comparative study has been carried out between the actual power plant and the model created in Cycle-Tempo, in this study. It was observed that not much variation took place when mass flow rates and temperatures at different points were compared. The highest variation in the values that were obtained happened to occur in the temperature value of the inlet of the low-pressure heater number 2. The error $\%$ at this point is $9.07 \%$, which falls in the acceptable range of error. The optimization of the power plant resulted in an increase of $0.1 \%$ in the overall efficiency of the power plant. Various parameters were found to affect the efficiency of the power plant. Efficiency was found to increase considerably with an increase in inlet air temperature to the compressor, whereas it decreased with increase in the condenser inlet pressure. Efficiency was found to increase slightly with increase in gain in cooling water temperature and overall power output. Exergy analysis shows that highest exergy loss takes place in the combustor, which is followed by the steam generator. The least exergy loss took place in the de-aerator. The overall exergy efficiency of the power plant was found to be $33.64 \%$.

Table 5: Nomenclature

\begin{tabular}{|c|l|}
\hline Symbol & \multicolumn{1}{|c|}{ Name } \\
\hline$\vec{E}$ & Rate of energy transfer (power), $\mathrm{kW}$ \\
\hline$g$ & Acceleration due to gravity $=9.81 \mathrm{~m} / \mathrm{s}^{2}$ \\
\hline$h$ & Enthalpy, $\mathrm{kJ} / \mathrm{kg}$ \\
\hline$h_{0}$ & Enthalpy at dead state, $\mathrm{kJ} / \mathrm{kg}$ \\
\hline$\dot{m}$ & Mass flow rate, $\mathrm{kg} / \mathrm{s}$ \\
\hline$\phi$ & Rate of heat transfer, $\mathrm{kW}$ \\
\hline$s$ & Entropy, $\mathrm{kJ} / \mathrm{kg}-\mathrm{K}$ \\
\hline
\end{tabular}




\begin{tabular}{|c|l|}
\hline$s_{0}$ & Entropy at the dead state, $\mathrm{kJ} / \mathrm{kg}-\mathrm{K}$ \\
\hline$T$ & Temperature, $\mathrm{K}$ \\
\hline$T_{0}$ & Temperature at the dead state, $\mathrm{K}$ \\
\hline$V$ & Velocity, $\mathrm{m} / \mathrm{s}$ \\
\hline$W$ & Rate of work (power), $\mathrm{kW}$ \\
\hline$X$ & Rate of Exergy Transfer, $\mathrm{kW}$ \\
\hline$z$ & Height, $\mathrm{m}$ \\
\hline$\eta$ & Efficiency \\
\hline$\eta_{I}$ & First law efficiency or Thermal efficiency \\
\hline$\eta_{U I}$ & Second law efficiency \\
\hline
\end{tabular}

\section{REFERENCES}

1. M. Sreekanth and Joseph Daniel, Implementing Results of Exergy Analysis in Steam Turbine Power Plants, International Journal of Applied Engineering Research, vol. 10, number 12 (2015) pp. 32113-32123

2. Reddy, V.S., Kaushik, S.C., and Panwar, N.L., 2013, “Review of power generation scenario in India”, Renewable and sustainable energy reviews, vol. 18 , pp. 43-48.

3. Regulagadda, P., Dincer, I. and Naterer, G.F., 2010, "Exergy analysis of a thermal power plant with measured boiler and turbine losses", Applied Thermal Engineering, vol. 30, pp. 970-976.

4. Ravinder Kumar, A critical review on energy, exergy, exergoeconomic and economic (4-E) analysis of thermal power plants, Engineering Science and Technology, an International Journal (2017) pp. 283-292.

5. Li, Y., and Liu, L., 2012, “Exergy analysis of 300 MW coal-fired power plant”, Energy Procedia, 2012 International Conference on Future Electrical Power and Energy Systems, vol. 17, pp. 926-932.

6. Mohamed Elhelwa, Kareem Saad Al Dahma, Abd el Hamid Attiaa (2019), Utilizing exergy analysis in studying the performance of steam power plant at two different operation mode, Applied Thermal Engineering (2019) pp. 285-293.

7. Dong Z, Li D, Wang Z, Sun M. A review on exergy analysis of aerospace power systems. ActaAstronautica. 2018 Nov 1;152:486-95.

8. Li W, Liu M, Yan J, Wang J, Chong D. Exergy analysis of centered water nozzle steam-water injector. Experimental Thermal and Fluid Science. 2018 Jun 1;94:77-88.

9. Hasan HuseyinErdema, Ali VolkanAkkaya, Burhanettin Cetin et al, Comparative energetic and exergetic performance analyses for coal-fired thermal power plants in Turkey, International Journal of Thermal Sciences (2009) pp. 2179-2186.

10. Aleksandr M. Kler, Yulia M. Potanina, Andrey Y. Marinchenko, Co-optimization of thermal power plant flowchart, thermodynamic cycle parameters, and design parameters of components, Energy (2020).

11. S.C. Kaushik, V. Siva Reddy, S.K. Tyagi, Energy and exergy analyses of thermal power plants: A review, Energy and exergy analyses of thermal power plants: A review (2011) pp. 1857-1872.

12. Sairam Adibhatla, S.C. Kaushik, Energy and exergy analysis of a super critical thermal power plant at various load conditions under constant and pure sliding pressure operation, Applied Thermal Engineering (2014) pp. 51-65.

13. M. Akbari Vakilabadi, M. Bidia, A.F. Najafi, Energy, Exergy analysis and optimization of solar thermal power plant with adding heat and water recovery system, Energy Conversion and Management (2018) pp. 1639-1650.

14. Shivendra Singh Chauhan, Shabina Khanam, Enhancement of efficiency for steam cycle of thermal power plants using process integration (2019) pp. 364-373.

15. M.K. Gupta, S.C. Kaushik, Exergy analysis and investigation for various feed water heaters of direct steam generation solar-thermal power plant, Renewable Energy (2010) pp. 1228-1235. 
16. C.O.C. Oko, I.H. Njoku, Performance analysis of an integrated gas-, steam- and organic fluid-cycle thermal power plant, Energy (2017) pp. 431-443.

17. Peng Fu, Ningling Wang, Ligang Wang et al, Performance degradation diagnosis of thermal power plants: A method based on advanced exergy analysis, Energy Conversion and Management (2016) pp. 219-229.

18. Ali Bolatturk, Ahmet Coskun, CaglarGeredelioglu, Thermodynamic and exergoeconomic analysis of Çayırhan thermal power plant, Energy Conversion and Management (2015) pp. 371-378.

19. Bidabadi M, Akbari Vakilabadi M, KhoeiniPoorfar A, Monteiro E, Rouboa A, Rahbari A. Mathematical modeling of premixed counterflow combustion of organic dust cloud. Renew Energy 2016;92:376-84.

20. Yunus A Cengel and Michael A Boles, 2010, “Thermodynamics: An Engineering Approach”, 6th Edition, Tata Mc Graw-Hill Companies.

21. Qadir, Sami Ullah, and Weqar Ahmad Siddiqui. "Effect of fly ash on some biochemical parameters of selected plants growing at dumping site of badarpur thermal power plant in Delhi." IMPACT: International Journal of Research in Applied, Natural and Social Sciences (IMPACT: IJRANSS) 2.7 (2014): 7-14.

22. Umair, Siddique Mohammed. "Equivalent Carbon Analysis of Thermal Power Plant." International Journal of Mechanical and Production Engineering Research and Development (IJMPERD) 4.2 (2014):45-50.

23. Pillai, Bindu, et al. "Automation and virtual simulation of laboratory based mini thermal power plant." International Journal of Mechanical and Production Engineering Research and Development (IJMPERD) 3.4 (2013): 69-76.

24. Geete, Ankur, and A. I. Khandwawala. "Exergy analysis for 120MW thermal power plant with different inlet temperature conditions." IMPACT: International Journal of Research in Engineering \& Technology (IMPACT: IJRET) 2.1 (2014): 21 -30.

25. Ogunwale, Olumuyiwa A., O T Popoola, and O O Daodu. "Exergy Analysis of Propane-Fuelled Valveless Pulsed Combustor." International Journal of Mechanical and Production Engineering Research and Development (IJMPERD) 10.2 (2020):523534 

